\title{
The Euro and the CFA Franc: Evidence of Sectoral
}

\section{Trade Effects}

\author{
Inmaculada Martínez-Zarzoso* \\ Georg-August Universität Göttingen, Germany and \\ Universitat Jaume I, Spain \\ Email: imartin@uni-goettingen.de
}

\begin{abstract}
This paper estimates a gravity model of trade to evaluate the trade effects of the Euro on sectoral trade within the Eurozone (EZ), the CFA Franc Zone (CFA) and between the EZ and the CFA, when CFA countries acquired fixed rates against the nonfrancophone EZ members. The formation of the EZ provides a quasi-natural experiment to estimate the effects on trade of fixed exchange rates, since the change in exchange rate regime for CFA countries with all EZ countries but France was not trade related. This is tested using sectoral trade data for 175 countries over the period 1995-2016 and validated using a longer time period starting in the seventies. The main departure from Frankel (2008), is the estimation of a structural gravity model using sectoral trade and bilateral-sectoral fixed effects as well as controls for multilateral resistance, namely time varying countrysector fixed-effects for exporters and importers, in a PPML framework. The main results indicate that the introduction of the Euro does show positive and significant effects for export flows from the CFA to other EZ countries different from France, whereas exports in the opposite direction are negatively affected. Moreover, the results differ by sector and we find that agricultural and homogeneous goods exports from CFA countries to Euro adopters increased by around forty and hundred twenty percent, respectively after the euro adoption.
\end{abstract}

JEL: F10, F14

Key Words: CFA, Euro Effect, Bilateral Trade, panel data, Rauch classification, sectoral trade, PPML, structural gravity

ACKNOWLEDGEMENT

Financial support received from the Spanish Ministry of Economy and Competitiveness, Project ECO2017-83255-C3-3-P (AEI, FEDER, EU) and from project UJI-B2017-33 is gratefully acknowledged. I also would like to thank the editor and the anonymous referee for their helpful comments and suggestions.

\footnotetext{
* Corresponding address: Department of Economics, University of Goettingen, Goettingen 37073 Germany. This is a post-peer-review, pre-copyedit version of an article published in Open Economies Review. The final authenticated version is available online at: http://dx.doi.org/ DOI: 10.1007/s11079-018-09520-8.
} 


\section{The Euro and the CFA Franc: Evidence of Sectoral Trade Effects}

\section{Introduction}

The controversial debate about the "Euro effect" following Rose (2000) identified several methodological problems that were disregarded in earlier empirical studies estimating the trade effects of currency unions. Later studies have found much lower effects -though still robust- but could not overcome concerns of an endogeneity bias. A number of authors, among them Baldwin (2006), Carrere (2004) and Frankel (2008), argue that in the case of the Euro and most other currency arrangements, it is hard to isolate the effect of fixed exchange rates on trade due to the endogeneity of the currency decision. Countries tend to cooperate more with geographically-close countries, with whom they also have strong cultural and historical ties, and in particular, monetary cooperation is usually accompanied with other trade-promoting integration attempts (Tapsoba, 2009; Diallo and Tapsoba, 2016).

In this context, the case of the African Financial Community ${ }^{1}$ (CFA), first examined by Carrere (2004) and Frankel (2008), deserves a second examination. The CFA franc is the name of two currencies, specifically the West African CFA franc, which is the official currency of the Economic and Monetary Union of West Africa (WAEMU), and the Central African CFA franc, which is the official currency of the Economic and Monetary Community of Central Africa (CEMAC). Despite being -theoretically- two currencies, they could be exchanged one-to-one through the Euro. These two currencies were pegged to the French Franc and with convertibility guaranteed by the French treasury ${ }^{2}$. As a by-product of the introduction of the Euro in 1999, the currencies of both monetary unions, WAEMU and CEMAC, have since been pegged to the Euro. This provides an interesting natural experiment, since WAEMU and CEMAC members had no intention of pegging their currency to the currencies of other EZ (EZ) members -excluding France- and this event is not linked to deeper integration between both African unions and EZ members. For these reasons, the link to the Euro with the CFA Franc could be considered exogenously determined. This allows us to isolate the

\footnotetext{
${ }^{1}$ CFA is the acronym for Communauté Financière Africaine (African Financial Community) - See more at: http://africanbusinessmagazine.com/uncategorised/a-brief-history-of-the-cfa-franc/\#sthash.OcjOKe7i.dpuf.

${ }^{2}$ Convertibility is still today guaranteed by France and, ultimately, by the European Central Bank. CFA countries must deposit half of their foreign-exchange reserves with the French treasury and French delegates are part of the CFA central banks' boards (The Economist, 2018).
} 
trade effect of this currency arrangement for countries involved in other trade promoting attempts and to quantify the effect without incurring an endogeneity bias affecting the currency decision. Carrere (2004) successfully separated the trade promoting effect of free trade agreements (FTA) from the effect of completely eliminating exchange rate volatility for the countries in CEMAC and WAEMU. She found that the introduction of the exchange rate volatility variable reduced the FTA effect by around 50 percent for countries in FTAs with a common currency.

In the context of the Euro Effect literature, Frankel $(2008,2010)$ investigates the impact of the fixed exchange rate effect between the EZ and the CFA Franc Zone (CFA) using a gravity model of trade to consider the exogeneity of the currency decision. He uses trade data for the years 1948-2006 and finds that bilateral trade between members of the EZ and the CFAis 76 percent higher after the introduction of the Euro, whereas trade within the CFA Franc Zone, decreased by 52 percent after the event -although the estimate is very imprecise and only significant at the 10 percent level-. We claim that the models used to obtain these effects for trade between the EZ and the CFAin Frankel $(2008,2010)$ omit multilateral resistance terms (MRT) leading to biased results ${ }^{3}$.

The pegging of fixed exchange rates has important advantages for the countries that opt for this monetary strategy. In particular, a pegged or fixed exchange rate makes trade less risky and the revenues of trading firms less uncertain and can reduce the likelihood of a currency crisis (Aizenman, 2018). On the other hand, this policy could generate problems with reserves and an inability to respond to external shocks (Carrere, 2004).

The main aim of this study is to quantify the effect of adopting the Euro on bilateral trade flows involving countries with a pegged exchange rate to the French franc. Similar to Frankel (2008), we claim that adoption of the Euro is strictly exogenous, with the African countries not having any economic or political motivation nor any influence in the decision of France to adopt the Euro. Departing from Frankel (2008), the modelling strategy consists of estimating a theoretically founded gravity model for export flows unidirectional trade flows- within the CFA and between the EZ and the CFA Franc Zone. We first use

\footnotetext{
${ }^{3}$ Rose (2017) explains the high variation in the estimates oft he EMU effect by examining systematic biases in MRT.
} 
disaggregated trade data for 175 countries over the years 1995-2016 and as robustness we use an extended sample for aggregated trade and for selected sectors over a longer period starting in 1973. More specifically, we depart from the approach in Frankel (2008) in two respects. First, we use panel data estimation methods, introducing MTR that are time variant, namely, time-varying country-sector dummies for exporters and importers and dyadic-sectoral fixed effects (dyadic fixed effects in the second sample) in a structural gravity model. Second, we distinguish between trade of different types of goods ${ }^{4}$, agricultural, minerals and manufactured goods (homogeneous and differentiated goods) and estimate sector-specific effects.

The main results indicate that the introduction of the Euro does show positive and significant effects for export flows from the CFAto EZ countries (excluding France), whereas exports in the opposite direction are negatively affected. Moreover, the results differ by sector and we find that agricultural and homogeneous goods exports from CFA countries to Euro adopters increased by around forty and hundred twenty percent, respectively after the euro adoption. The results also indicate that the introduction of the Euro is associated with positive trade effects for intra-CFA exports of mine and minerals and manufactured goods, and mostly differentiated goods.

The rest of the paper is structured as follows: Section 2 describes the CFA and Section 3 revises the related literature. Section 4 presents the data, variables and model specification and the main empirical results and robustness checks are presented in Section 5. Finally, Section 6 concludes.

\section{The CFA Zones}

The two CFA Franc Zones -the WAEMU ${ }^{5}$ and the CEMAC ${ }^{6}$ - were created in 1945 by linking two currency unions with a pegged exchange rate between their currencies and the French Franc. As both currency

\footnotetext{
${ }^{4}$ Defined according to Rauch (1999) classification.

${ }^{5}$ In 2012 consisting of Benin, Burkina Faso, Ivory Coast, Guinea-Bissau, Mali, Niger, Senegal and Togo. See Figure A.1.

${ }^{6}$ In 2012 consisting of Cameroon, Central African Republic, Chad, Republic of Congo, Equatorial Guinea and Gabon.
} 
unions have had the same fixed exchange rate with respect to the French Franc and later to the Euro ${ }^{7}$, the exchange rate between both CFA Franc zones equals one ${ }^{8}$.

All member states of the CFA Franc zones are Sub-Saharan African countries and all but Guinea-Bissau and Equatorial Guinea were French colonies before gaining independence. A unique feature of both currency unions was the involvement of France as the anchor currency country in the monetary policy of the central banks of the WAEMU and CEMAC. France guaranteed the convertibility into their own currency and participated in the executive boards of the central banks with veto power and thus the ability to block any decisions until the adoption of the Euro. In fact, the CFA Franc Zones went beyond the features of a regular currency union. With the devaluation imposed by France in $1994^{9}$, very similar rules of macroeconomic surveillance to those established in the EMU were introduced and gradually implemented. The three main convergence criteria are an inflation rate below 3 percent, a debt-to-GDP ratio below 70 percent and a balanced budget (Hallet 2008).

The fixed peg of the CFA Franc to the French Franc/Euro serves as an important anchor for monetary policy for the CFA members. As a disadvantage, it implies the lack of monetary and exchange rate policies as an option to support a smooth adjustment to regional or country-specific shocks. According to Hallet (2008) and Tapsoba (2009), the common currency has significantly contributed to achieving higher macroeconomic stability in the area than in other Sub-Saharan African countries. The convertibility to the French Franc/Euro facilitates external transactions and provides the CFA Franc zones with credibility and stability. This is broadly seen as enhancing the conditions for trade in general and not only for trade within the currency union. In this sense, it could be expected that trade diversion with the rest of the world attributed to the currency unions will be less likely to happen since convertibility is guaranteed by France or by the European Central Bank after the Euro (Carrere, 2004).

\footnotetext{
${ }^{7}$ Since the last devaluation of the CFA Franc in 1994, the fixed exchange rates are FF $1=$ CFA 100 and Euro $1=$ CFA 655.957.

${ }^{8}$ However, the central banks of the two CFA monetary unions decided in 1993 that notes presented outside the unions could not be exchanged (Carrere, 2004).

${ }^{9}$ The CFA Franc lost $50 \%$ of its value. One French Franc was worth 50 CFA Francs before the devaluation and 100 after. It was an important shock for the CFA economies, which led to a high increase in the price of imported goods and deteriorated the living standards of the population in the short run.
} 
Nevertheless, while monetary integration is well established, economic integration is still incomplete in the WAEMU and CEMAC areas. A weak economic environment and a high dependence on commodity exports increase the likelihood of asymmetric shocks and of pro-cyclical fiscal behaviour. This is the main reason why overall compliance with the aforementioned convergence criteria has often been insufficient in most of the member countries.

\section{Literature Review}

The analysis and quantification of the trade effects derived from the CFA Franc as a common currency, with two currency unions involved and linked to the Euro with a fixed peg, is not an easy task. While trade effects of a currency union may occur within the two different CFA Franc zones, there may also be trade effects derived from a fixed peg between them, the WAEMU and CEMAC, and between the EZ and the CFA Franc zones.

There is extensive literature investigating both effects, which are very much related, since forming a currency union and linking two currencies with a fixed peg both imply the elimination of any volatility in the nominal bilateral exchange rate ${ }^{10}$.

The empirical literature investigating the trade effects of exchange rate volatility generally finds mixed results. Most studies show non-significant or weakly significant negative effects ${ }^{11}$. In sharp contrast to these results, studies investigating trade effects of currency unions usually find robust positive effects. While some studies found extremely positive results of up to a 200 percent increase in trade (Rose, 2000; Glick and Rose, 2002; Frankel, 2010), other studies find smaller magnitudes -a positive effect between 530 percent- still robust and statistically significant (Flam and Nordström, 2003; Micco el al, 2003; Kelejian et al, 2012; Baldwin et al, 2008; Glick and Rose, 2016). Most of the recent studies have focused on trade

\footnotetext{
${ }^{10}$ Given the one to one convertibility between both CFA francs and the fact that France is the anchor currency with significant influence on the central bank policy for both currencies, one might also consider the two monetary unions of the CFA as one large currency union. In the core of this study, we do not distinguish between both currency unions and treat the CFA Franc as a single currency union. We add as robustness check an estimation of separated effects for both areas.
}

\footnotetext{
${ }^{11}$ See survey papers on the relationship between exchange rate volatility and trade from McKenzie (1999), Ozturk (2006), Bahmani-Oskooee \& Hegerty (2007) and Auboin \& Ruta (2011).
} 
effects of the EZ and not in currency unions in general ${ }^{12}$ and have been restricted to examining the trade effects not only of currency unions, but also of exchange rate volatility in industrialized countries. In contrast, studies for developing and especially Sub-Saharan African countries are scarce. An exception is Fielding \& Shields (2005), who investigate the impact of the CFA Franc on macroeconomic integration in the form of trade intensity and business cycle synchronisation for the years 1981-2000. They find evidence of positive effects for intra- and inter-CFA zone trade that are declining over time. The results for the early years are of a similar magnitude as those found by Rose (2000) using a global sample. Fielding \& Shields (2005) state that the smaller magnitude of the effects obtained for more recent years, especially for the fixed exchange rate effect of inter-CFA zone trade, can be explained by the high correlation existing between exchange rate stability and other forms of macroeconomic policy stability. Reforms in this field in countries with flexible exchange rates reduce potential gains stemming from exchange rate stability.

Carrere (2004) analysed the effect of regional trade agreements and currency unions on trade in SubSaharan Africa for the period from 1962 to 1996 using a gravity model. The model is estimated using a Hausman-Taylor estimator with bilateral fixed effects to control for the endogeneity of the target variables. In particular, she found that the currency unions in the two agreements of the CFA franc zones -the WAEMU and CEMAC- have increased intra-regional trade beyond the increase generated by the corresponding free trade agreements and have in turn mitigated trade diversion with the rest of the world. The main explanation for a lower trade diversion is that convertibility, guaranteed by the French (or the European central bank after the Euro), makes transactions with the rest of the world easier and safer for the CFA franc zones' members than for other comparable African countries. Meanwhile, Girardini and Sall (2018) highlight the differences between CEMAC with little intra-zone trade and WAEMU with higher intrazone trade but with important asymmetries given country sizes dissimilarities among its members. Tapsoba (2009) investigates whether the effect of the two African monetary Unions on trade more than compensates for the negative impact of asymmetric shocks among African countries, which the author

\footnotetext{
${ }^{12}$ An excellent overview of the literature can be found in Baldwin (2006).
} 
named 'the endogeneity effect'. The author finds that intra-African trade increases the co-movement of African business cycles, but the magnitude of the effect is smaller than similar estimates among developed countries. Dialo and Tapsoba (2016) specifically focus on the changes in business cycle patterns in SubSaharan Africa and the rising influence of trade links with BRIC countries. They find that synchronization with these countries has increased in the last decade, mainly due to increasing trade and integration, whereas it has decreased with G7 countries. Moreover, they state that not only regional integration, but also currency unions amplify the impact of trade on business cycle synchronization.

Masson (2008) evaluates whether currency unions in Sub-Saharan Africa are justified by positive trade effects. He argues that due to asymmetries across countries and the low level of trade amongst members, a selective expansion of existing fixed exchange rate agreements, such as the CFAor the adoption of a foreign currency, such as the Euro in the form of a dollarization, would be preferable than the formation of new currency unions in the area. In addition, he finds that other trade facilitation targets, such as improving infrastructure, political stability and efficient merchandise handling, are more effective in increasing trade than solely focusing on the formation of a currency union.

Tsangarides et al. (2006) investigate the trade effects of currency unions using an augmented version of the gravity model of trade for the case of Africa with data for 217 countries over the period 1948-2002. They find that a pair of countries that are members of the same currency union trade 100 percent more than others and that the size of the effect is very similar for African countries and the whole sample. They also find that the trade effect is not associated with trade diversion from non-currency-union members and is stronger the longer the mutual currency union membership persists.

The relative importance of the exchange rate in comparison to other variables in explaining the "border effect puzzle" is evaluated in De Sousa \& Lochard (2005). The authors estimate a gravity model of trade and find that between 17 and 28 percent of the total border effect for the CFAis caused by currency related effects such as currency handling and exchange rate uncertainty.

The evaluation of the effect of fixed exchange rate regimes on trade, which imply the elimination of any volatility in the nominal bilateral exchange rate, is addressed by Frankel (2008) in the context of the CFA 
and the Euro, as already described in the introduction, and more recently by Baranga (2014) in a more general context. Baranga (2014) estimates the causal impact of a change in the exchange regime on aggregate trade and finds that estimates from a traditional gravity equation framework are biased up by the tendency of countries that stabilize their currencies to do so mainly with respect to major trading partners.

Finally, in a descriptive study, Hallet (2008) reports a declining share of trade for the CFAwith the EZ in the past decades. He attributes this to the longer-term adjustment from colonial economic ties and the increasing importance of emerging economies in Asia in more recent years. They conclude that in addition to political instability, infrastructure and merchandise handling, currency related problems appear to be an important constraint for trade in Sub-Saharan Africa.

To summarize, empirical results generally indicate positive effects of trade between the CFA zone and the EZ and no signs of trade diversion even in more recent periods, despite the decreasing relative importance of the EZ in trade for the CFAfound in Hallet (2008). Meanwhile, results on the trade effects within the CFAare generally mixed, indicating that the CFAhas not substantially contributed to regional trade integration.

Most of the above-mentioned studies restrict their investigation to aggregate trade effects and do not distinguish between different types of products ${ }^{13}$.

\section{Data, Variables and Empirical Strategy}

\subsection{Data and Variables}

The main dataset of this study covers 175 countries (See Table A.1 in the Appendix) for the years 19952016 and 69 categories of goods. Data on bilateral trade flows are reported at the 2-digit level of the Standard International Trade Classification (SITC) Rev. 2 from UN-Comtrade. Products are classified into four different groups: agricultural goods (1), mining (2), manufactured homogenous and referenced priced goods (3) and manufactured differentiated goods (4). The goods have been classified according to the

\footnotetext{
${ }^{13}$ Baldwin et al (2005) and Flam and Nordström (2006) estimate sectoral effects for the adoption of the Euro.
} 
conversion table proposed in Rauch (1999) as shown in Table A.2 in the Appendix. The relative size of the trade volume of the four groups of goods is shown in the first part of Table 1 for different directions of flows. It underlines the importance of agricultural goods and mining for exports from CFA members and the exports of manufactures for the EZ. The second and third parts of Table 1 show the average exports by country group before and after the EZ was created, respectively. Average exports within the CFA zone are significantly higher after 1999, especially in agricultural products and homogeneous and referenced price manufactures. The same is the case for some trade flows between CFA and France, whereas in general, trade between EZ countries and CFA countries is not significantly higher after the euro adoption.

Data on distance and common gravity variables are from CEPII ${ }^{14}$ and data on regional trade agreements (RTAs) and currency unions (CUs) are from De Sousa (2012) and have been actualized until 2016. Information on CFAmembership was taken from the Banque Centrale des États d'Afrique Centrale (BEAC) and the Banque Centrale des États de l'Afrique de l'Ouest (BCEAO) and EZ membership is from Eurostat. All variables in the model are described in Table A.2 in the Appendix.

Table 1: Average Export Shares by Categories and Average Exports

\begin{tabular}{|c|c|c|c|c|c|c|}
\hline Code & Description & Intra-CFA & $\begin{array}{l}\text { CFA to } \\
\text { France }\end{array}$ & $\begin{array}{l}\text { France to } \\
\text { CFA }\end{array}$ & CFA to EZ & EZ to CFA \\
\hline & & $\%$ & $\%$ & $\%$ & $\%$ & $\%$ \\
\hline \multicolumn{7}{|c|}{ Average Shares over Total Exports } \\
\hline 1 & Agricultural Goods & 39.01 & 49.06 & 19.80 & 73.38 & 32.36 \\
\hline 2 & Mining & 20.48 & 25.16 & 5.11 & 24.08 & 11.18 \\
\hline 3 & Homogeneous\&Referenced Price & 14.87 & 4.78 & 17.88 & 5.67 & 16.35 \\
\hline 4 & Differentiated & 57.54 & 24.21 & 57.26 & 35.14 & 58.36 \\
\hline \multicolumn{7}{|c|}{ Average In exports until 1998} \\
\hline & All goods & 12.747 & 15.394 & 15.707 & 13.193 & 13.412 \\
\hline 1 & Agricultural Goods & 12.953 & 16.208 & 17.354 & 14.311 & 14.039 \\
\hline 2 & Mining & 12.735 & 15.271 & 15.313 & 13.430 & 12.772 \\
\hline 3 & Homogeneous\&Referenced Price & 12.932 & 15.606 & 18.799 & 12.269 & 14.024 \\
\hline 4 & Differentiated & 10.959 & 11.965 & 11.267 & 10.716 & 11.550 \\
\hline \multicolumn{7}{|c|}{ Average In exports after 1998} \\
\hline & All goods & $13.010 *$ & 15.41 & $16.47^{*}$ & 13.191 & 13.52 \\
\hline 1 & Agricultural Goods & $13.713^{*}$ & 16.525 & 17.395 & 14.471 & 13.920 \\
\hline
\end{tabular}


Note: ${ }^{*} 0.05$ denote significance level of a test of difference in means before and after 1999.

\subsection{Empirical strategy}

We estimate an augmented version of the gravity model of trade, which explains bilateral trade between countries as a function of their respective economic masses, the distance between them and a variety of other factors using panel data techniques (Head and Mayer, 2014; Baltagi et al, 2014). The pseudo-poisson maximum likelihood (PPML) proposed by Santos-Silva and Tenreyro (2006) provides a solution for two prevalent estimation issues that affect log-transformed gravity models. First, the model in log-log form could suffer from heteroscedasticity and second, the transformation disregards the information of the zero values in the dependent variable. According to Fally (2015), one additional reason to choose PPML is its resemblance with the roots of structural gravity equation using fixed effects to control for multilateral resistance terms (MRT).

To control for unobserved heterogeneity, we introduce several sets of fixed effects ${ }^{15}$. Allowing for time variation in country fixed-effects is more consistent with the theoretical concept of "multilateral resistance" proposed by Anderson \& van Wincoop (2003), as MRT are likely to vary over time. Furthermore, when sectoral data are used, the MRT should also vary by sector. Therefore, country-time varying dummies for each SITC goods category are added to control for industry specific differences. For comparative purposes, the gravity model is also estimated with the usual gravity bilateral time invariant factors and MRT.

The baseline estimated model is given by, Exports $_{i j k t}=\exp \left(\beta_{1} \mathrm{CFAEZ}_{\mathrm{ijt}}+\beta_{2} \mathrm{EZCFA}_{\mathrm{ijt}}+\beta_{3}\right.$ intraCFA $_{i j t}+$ $+\beta 4$ CFAFranceijt $+\beta$ FranceCFAijt $+\beta$ 6lnDistanceij $+\beta 7$ Borderij $+\beta 8$ ComLanguageij $+\beta 9$ Colonyij $+\beta 10 R T$ Aijt $+\beta 11$ CUi $j t+\beta 12 E U R O i j t+\pi i k t+\tau j k t) x \varepsilon i j k t$

\footnotetext{
${ }^{15}$ Given the inclusion of time-variant MRT, the GDP coefficients are not identified in the estimations. Hence, the GDP variables included in the traditional gravity model of trade are dropped.
} 
where Exports $\mathrm{ijkt}_{\mathrm{jkt}}$ denotes bilateral exports of sector $\mathrm{k}$ from country $\mathrm{i}$ to $\mathrm{j}$ at time $\mathrm{t}$, Distance $\mathrm{i}_{\mathrm{j}}$ is the distance between both countries' capitals. We include dummy variables to identify trade flows from the CFA to the EZ $\left(C F A-E Z_{i j t}\right)^{16}$, the EZ to the CFA (EZ-CFA $\left.A_{i j t}\right)$, between CFA members (Intra-CFA $A_{i j t}$ ), from the CFA to France (CFA-France $\mathrm{ijt}_{\mathrm{it}}$ ) and from France to the CFA (France-CFA $\left.A_{\mathrm{ijt}}\right)^{17}$. Border ${ }_{\mathrm{ij}}$ is a dummy variable that equals one if both countries share a border, zero otherwise, Language $_{\mathrm{ij}}$ equals one if a language is spoken by at least nine percent of the population in both countries. Colony $y_{i j}$ is a dummy variable that equals one if countries $i$ and $\mathrm{j}$ have ever had colonial ties, $\mathrm{RTA}_{\mathrm{ijt}}$ equals one if both countries have signed a regional trade agreement and $\mathrm{CU}_{\mathrm{ijt}}{ }^{18}$ equals one if both countries are members of the same currency union, zero otherwise (excluding the $E Z$ and the CFA). $E U R O_{i j t}$ equals one if both countries are members of the $E Z$, zero otherwise. Finally, $\pi_{i k t}$ and $\tau_{j k t}$ are dummy variables that vary by origin-sector and time and destination-sector and time and are used as proxies for MRT.

A second specification incorporates bilateral unobserved heterogeneity modelled using fixed effects that are specific to each bilateral relationship and sector (ijk dimension). The coefficient of the variables that are time invariant in specification (1), namely distance, colony, common language and border dummies cannot be directly estimated. Hence, the specification includes bilateral-sectoral fixed effects, $\delta_{i j k}$, and MRT and is given by:

$$
\begin{aligned}
\text { Exports }_{i j k t}= & \exp \left(\alpha_{1} \mathrm{CFAEZ}_{\mathrm{ijt}}+\alpha_{2} \mathrm{EZCFA}_{\mathrm{ijt}}+\alpha_{3} \text { intraCFA }_{i j t}+\alpha_{4} R T A_{i j t}+\alpha_{5} C_{i j t}+\alpha_{6} E U R O_{i j t}+\delta_{i j k}+\pi_{i k t}\right. \\
& \left.+\tau_{j k t}\right) x \varepsilon_{i j k t}
\end{aligned}
$$

where $\pi_{i t}$ and $\tau_{j t}$ are the MRT.

\footnotetext{
${ }^{16}$ EZ excludes France.

${ }^{17}$ Dummy variables identifying trade flows between the Eurozone and the CFA take the value zero if the exporting or importing country is France as these flows are identified by additional variables. We have separated the Euro effect from the common currency effect in the model specification by including a Euro dummy and excluding the Eurozone from the common currency dummy. Moreover, the intraCFA and the FranceCFA dummies only take the value of 1 after 1999 to compare trade within these groups before and after adoption of the Euro.

${ }^{18}$ The currency union dummy variable takes the value zero when both countries are members of the CFA as the dummy variable for mutual CFA Zone membership already captures this.
} 
Model (2) is estimated for all sectors and for groups of sectors classified according to Rauch (1999) classification; the results are presented in the next section.

\section{Empirical Results}

\subsection{Main results}

Results for the GM estimations including all sectors are shown in Table 2. All estimations are done using the iterative algorithm of Zylkin $(2017)^{19}$, a PPML with high-dimensional fixed effects. The first column shows results for specification (1) with country-time-and-sectoral dummies included along with separated effects for France (CFAFrance, FranceCFA) and the Euro-group without France (EZCFA, CFAEZ) and column (2) shows the results dropping the CFAFrance and FranceCFA dummy variable. If French trade with CFA countries is higher than with the rest of countries also after 1999, this could be due to different reasons as to having a common currency. Columns (3) and (4) show the same set of results using bilateral-sector fixed effects, which accounts for all the time invariant factors that vary bilaterally and by sector. MRT modelled as importer-sector-and-time and exporter-sector-and-time Fixed-Effects are included in all four columns.

To discuss the results, trade effects of the currency agreements are converted into percentage changes in trade. In column (2) we observe that trade within the CFA area is $195^{20}$ percent higher than within other country groups after 1999.

The variables FranceCFA and CFAFrance are also indicating much higher volumes of trade between France and CFA countries after 1999 in comparison to other country groups, indicating that France could have acted as a hub for trade between CFA countries and other EZ countries. However, this is not the case for trade between non-francophone EZ countries and CFA countries, which is not significantly different from trade among other country groups for exports from CFA countries to EZ countries and negative and significant in the opposite direction.

\footnotetext{
${ }^{19}$ The PPML algorithm dramatically improves computational speed when including a full set of fixed effects in comparison with other available methods.

${ }^{20}$ The percentage change in trade is calculated as $195=(\exp (1.082)-1) * 100$ using the coefficient of the intraCFA dummy in column (2) of Table 2.
} 
The estimates for the currency union effect (excluding the Euro and the CFA) are not statistically different from zero, whereas the regional trade agreement dummy indicates higher volumes of trade in the presence of trade agreements. The main drawback of these results is that some bilateral unobserved heterogeneity that is sector specific, could be biasing the results and for this reason columns (3) and (4) show the results of the within estimator for specification (2) in the previous section.

Estimates in column (3) show that intra-CFA trade within each sector is higher after the implementation of the Euro in comparison to before, and exports from non-francophone countries to CFA countries are still lower within sectors after implementation of the Euro. Now both the Euro effect and the common currency effects are positive and significant ${ }^{21}$, which indicates that trade within the EZ is around 41 percent ${ }^{22}$ higher than before the Euro and on average, within other currency unions, trade is around 94 percent higher than when the corresponding countries were non-members. Concerning other control variables, all show the expected sign and magnitudes and are statistically significant. Variables measuring distance, contiguity, common language, and colonial relations are shown in columns (1) and (2) (in Table 2), but dropped from the FE regressions in columns (3) and (4) due to perfect collinearity with the FE as these variables do not vary over time. Distance between capitals has a significant negative impact on exports, which is below unity. In addition, contiguity of the two trading partners, common language and colonial relationship all have significant and positive effects on exports. Finally, in column (5) the bilateral FE are not restricted to be symmetric and standard errors are clustered by exporter, importer, sector and year (multi-way), which as indicated in Larch et al (2018) is the most conservative approach. In this case, the only statistically significant effect is for exports from CFA countries to EZ countries after the Euro, indicating that export increased by 15 percent in average. Since this average effect can hide important differences across sectors, we present in the Table 3, sectoral estimates.

Table 2. Estimation Results: Gravity Model with Time-Varying Multilateral Resistance Terms

\footnotetext{
${ }^{21}$ Estimates of the Euro effect in columns (3) and (4) are slightly higher to Glick and Rose (2016) in Table 5, columns (3) and (5).

${ }^{22}$ The volume effect can be calculated in percentage terms using the estimate of the EURO variable in column (4) of Table 2 as $[\operatorname{EXP}(0.346)-1]=0.413$.
} 


\begin{tabular}{|c|c|c|c|c|c|}
\hline $\begin{array}{l}\text { Dependent } \\
\text { Var.: } \\
\text { X_all sectors }\end{array}$ & with France & $\begin{array}{c}\text { (2) } \\
\text { without }\end{array}$ & $\begin{array}{c}\text { (3) } \\
\text { with France }\end{array}$ & $\begin{array}{c}\text { (4) } \\
\text { without }\end{array}$ & $\begin{array}{c}\text { (5) } \\
\text { Multi- } \\
\text { clustering }\end{array}$ \\
\hline \multicolumn{6}{|l|}{$\begin{array}{l}\text { Explanatory } \\
\text { Var.: }\end{array}$} \\
\hline \multirow[t]{2}{*}{ RTA } & $0.418^{* * *}$ & $0.417^{* * *}$ & $0.283^{* * *}$ & $0.284^{* * *}$ & 0.00811 \\
\hline & {$[0.00687]$} & [0.00687] & [0.0229] & [0.0229] & {$[0.0342]$} \\
\hline \multirow[t]{2}{*}{$\mathrm{CU}$} & $-1.099 * * *$ & $-1.099 * * *$ & $0.663 * * *$ & $0.663 * * *$ & 0.0295 \\
\hline & [0.0338] & [0.0338] & {$[0.0376]$} & [0.0375] & [0.0679] \\
\hline \multirow[t]{2}{*}{ EURO } & $0.233 * * *$ & $0.230 * * *$ & $0.347^{* * *}$ & $0.346 * * *$ & $-0.0504 *$ \\
\hline & [0.00962] & [0.00962] & [0.0219] & [0.0219] & [0.0259] \\
\hline \multirow[t]{2}{*}{ CFA } & $1.324 * * *$ & $1.082^{* * *}$ & $0.739 * * *$ & $0.662 * * *$ & 0.277 \\
\hline & [0.106] & [0.0979] & {$[0.0806]$} & {$[0.0780]$} & [0.170] \\
\hline \multirow[t]{2}{*}{ EZCFA } & $-0.255^{* * *}$ & $-0.455 * * *$ & $-0.433 * * *$ & $-0.518 * * *$ & -0.144 \\
\hline & {$[0.0560]$} & [0.0536] & [0.0538] & [0.0518] & [0.169] \\
\hline \multirow[t]{2}{*}{ CFAEZ } & 0.175 & 0.107 & -0.0516 & $-0.120 * *$ & $0.141 * * *$ \\
\hline & [0.116] & [0.111] & [0.0517] & [0.0495] & {$[0.0258]$} \\
\hline \multirow[t]{2}{*}{ FranceCFA } & $1.307^{* * *}$ & & $1.105^{* * *}$ & & \\
\hline & [0.0367] & & [0.0304] & & \\
\hline \multirow[t]{2}{*}{ CFAFrance } & $0.547^{* * *}$ & & $0.902 * * *$ & & \\
\hline & [0.102] & & {$[0.0702]$} & & \\
\hline \multirow[t]{2}{*}{ Ln Dist } & $-0.781 * * *$ & $-0.781 * * *$ & & & \\
\hline & [0.00296] & [0.00296] & & & \\
\hline \multirow[t]{2}{*}{ Colony } & $0.262^{* * *}$ & $0.262^{* * *}$ & & & \\
\hline & {$[0.0231]$} & {$[0.0231]$} & & & \\
\hline \multirow[t]{2}{*}{ ComLanguage } & $0.267^{* * *}$ & $0.272^{* * *}$ & & & \\
\hline & [0.00709] & [0.00707] & & & \\
\hline \multirow[t]{2}{*}{ Contiguity } & $0.596 * * *$ & $0.595^{* * *}$ & & & \\
\hline & [0.00705] & [0.00705] & & & \\
\hline BSFE & No & No & Yes & Yes & Yes \\
\hline Observations & $7,262,135$ & $7,262,135$ & $7,262,120$ & $7,262,120$ & $7,262,115$ \\
\hline R-squared & 0.875 & 0.875 & 0.987 & 0.987 & 0.990 \\
\hline
\end{tabular}

Note: Robust standard errors clustered by pair-sector in columns (1) to (4) and by exporter, importer, sector and year in column (5) are in brackets. $* * * p<0.01$, ** $\mathrm{p}<0.05$, * $\mathrm{p}<0.1$. Symmetric BSFE used in columns (3) and (4). BSFE denotes bilateralsectoral fixed effects. MRT is specified as exporter-sector-time and importer-sector-time dummy variables for each year. Estimations based on yearly data.

Results for each group of sectors are shown in Table 3 for model specification (2) with bilateral-sectoral fixed effects and exporter-sector-time and importer-sector-time dummy variables. Multi-way clustered standard errors, clustered by exporter, importer, sector and year are used (as in Table 2, column 5). As expected, estimated effects for CFA-EZ trade links differ to a large extent between sectors and by direction of the flow.

According to the estimates shown in Table 3 (column 1), exports from CFA members to EZ members are around 36 percent higher than before adoption of the Euro for agricultural products, whereas trade in the opposite direction -exports from EZ countries to CFA countries- are 36 percent lower than before 1999. 
Moreover, for homogeneous and referenced price goods the adoption of the Euro brings higher exports from CFA countries to the EZ and the increase is about 120 percent. However, Exports from the EZ to the CFA yield negative and significant results for exports of minerals and homogeneous products and nonstatistically significant estimates for the differentiated goods.

Trade within the CFA zone is significantly higher after the adoption of the Euro for all sectors apart from agricultural products (according to results in Table 3). In particular, trade is 45 percent higher for homogenous and referenced priced goods and 61 percent higher for differentiated goods. Given that trade in manufactures accounts for more that 50 percent of total trade within the CFA (Table 1), the overall effects for intra CFA trade flows can also be expected to be positive.

Concerning the effect of regional integration and the resulting reductions in trade barriers, we find insignificant impact of RTAs on trade in all regressions, when the multi-clustering option is used. Also currency unions (CU) have a mostly non-statistically significant effect on trade, with the only exception of homogenous and referenced price goods for which the effect is positive and significant at the ten percent level, whereas the Euro effect is not statistically significant for all sectors but one: differentiated goods, for which it is negative and significant.

Table 3. Results by Sector with Multilateral Resistance Terms and Without France

\begin{tabular}{lcccc}
\hline $\begin{array}{l}\text { Dependent } \\
\text { Var.: }\end{array}$ & $\begin{array}{c}(1) \\
\text { Exports S1 }\end{array}$ & $\begin{array}{c}(2) \\
\text { Exports S2 }\end{array}$ & $\begin{array}{c}(3) \\
\text { Exports S3 }\end{array}$ & $\begin{array}{c}(4) \\
\text { Exports S4 }\end{array}$ \\
\hline $\begin{array}{l}\text { Explanatory } \\
\text { Var.: }\end{array}$ & & & & \\
RTA & -0.0250 & 0.0515 & 0.0151 & 0.00334 \\
& {$[0.0406]$} & {$[0.0725]$} & {$[0.0462]$} & {$[0.0481]$} \\
CU & 0.0941 & 0.0465 & $0.0901^{*}$ & -0.0119 \\
& {$[0.0668]$} & {$[0.450]$} & {$[0.0495]$} & {$[0.0505]$} \\
EURO & -0.0378 & -0.0540 & 0.0233 & $-0.0679 * *$ \\
& {$[0.0471]$} & {$[0.126]$} & {$[0.0429]$} & {$[0.0312]$} \\
CFA & -0.218 & $0.861^{*}$ & $0.372 * * *$ & $0.477^{* *}$ \\
& {$[0.266]$} & {$[0.507]$} & {$[0.0996]$} & {$[0.217]$} \\
EZCFA & $-0.443^{* *}$ & $-1.104^{* *}$ & $-0.290^{* *}$ & 0.200 \\
& {$[0.178]$} & {$[0.552]$} & {$[0.145]$} & {$[0.158]$} \\
CFAEZ & $0.305^{*}$ & $-0.148^{*}$ & $0.790^{* * *}$ & 0.771 \\
& {$[0.183]$} & {$[0.0787]$} & {$[0.270]$} & {$[0.543]$} \\
BSFE & Yes & Yes & Yes & Yes \\
Observations & $1,917,698$ & 485,052 & $1,023,701$ & $3,835,664$
\end{tabular}


Note: Multi-way robust standard errors clustered by exporter, importer, sector and year are in brackets. $* * * \mathrm{p}<0.01, * * \mathrm{p}<0.05, *$ $\mathrm{p}<0.1$. BSFE denotes bilateral-sectoral fixed effects. MRT is specified as exporter-sector-time and importer-sector-time dummy variables for each year. Estimations based on yearly data. S1-S4 denote respectively agricultural products, minerals, homogenous and referenced priced manufactured products and differentiated manufactured products (see Table A.2).

\subsection{Robustness}

As a first robustness check, a replication of Table 7A in Frankel (2008) is shown in Table A.4 (in the Appendix). Similar to Frankel (2008), we have included bi-directional time-variant effects for the trade flows between CFA countries and EZ countries, instead of separate effects for each direction of exports CFAEZ and EZCFA- as in Tables 2 and 3 in the main results. Column (1) reports OLS results with time dummies, as in Frankel (2008) ${ }^{23}$, column (2) adds dyadic (bilateral) FE and column (3) contains dyadic FE and multilateral resistance terms. The main results indicate that our comparable specification to Frankel (2008) reports positive and significant effects on trade between CFA and EZ countries after 1999 for all years; however, the results in Frankel (2008) are positive and significant from 1997 to 2003 but fade away every year after 2004 (see Frankel (2008) column 4 in Table A.7, page 31). When adding dyadic fixed effects in our sample, in column (2), the trade effects between CFA and EZ countries are all negative and significant and when controlling in addition for MRT, in column (3), the effects for the three first years of the EZ are positive and significant, but after 2001 the yearly effects are again negative and significant. Summarizing, with a theoretically justified specification of the GM, only small short run positive increases in CFA-EZ trade are found, which are more than compensated with negative effects after 2002.

Next, as a second robustness check, the results using aggregated exports for all countries since 1973 and for selected sectors are presented in Table A.5 and a separation of the effects for the WAEMU and the CEMAC zones using aggregate exports are presented in Table A.6.

The results concerning the target variables, EZCFA and CFAEZ indicate that aggregated exports (column 1, Table A.5) are not significantly higher after the adoption of the Euro than before for trade flows between

\footnotetext{
${ }^{23}$ For completeness column (4) reports the original estimates in Frankel (2008): Table 7A in page 31, with a comparable model specification to column (1) using our dataset and including distance. However, Frankel (2008) dataset is for the period 1948-2006 and his dependent variable is a country- pair's total bilateral trade, rather than unidirectional exports. Moreover, Frankel does not include distance, importer or exporter fixed effects in his gravity equation.
} 
CFA and non-francophone EZ countries. The same is the case for non-energy exports and raw materials. The results are however positive and significant in three occasions -for food products exports, for machinery and transport equipment and for other manufactures from CFA to the EZ- at the one, five and ten percent significance level, respectively. Concerning intraCFA trade flows, with this extended sample intraCFA exports appear to be 143 percent higher on average after the Euro adoption, due to increases in exports of most sectors apart from raw materials. Also the Euro effect is positive and significant for raw materials and for exports of agricultural goods.

Finally, the results in Table A.6 indicate that the intraCFA trade effects found in Table A.5 for aggregated exports are mainly due to an increase in trade among WAEMU countries in some sectors, after 1999, whereas the dummy for intraCEMAC exports presents a non-significant coefficient for aggregate exports, but positive and significant for food exports. Exports from CEMAC to EZ countries are higher in agricultural and raw materials after the euro, whereas exports from WAEMU to EZ are higher on food and on manufactured goods after the euro.

\section{Conclusions}

The results of this study shed light on sectoral differences and the general robustness of trade effects from currency unions, which are generally found to be heterogeneous across sectors and currency unions. In sharp contrast to findings obtained by other authors, we find that the elimination of nominal exchange rate volatility between the CFA and the EZ has not boosted total trade between countries of both zones to a similar level as for trade of the former sole anchor currency (France) with the CFA Franc Zone. However, for some types of goods the effect is significant and in a few cases positive when using a sample of sectoral trade at 2-digit level. At the same time, we find positive effects for trade within the CFA and for exports from the CFA to the EZ after the Euro adoption for agricultural goods and homogenous goods.

This finding is particularly interesting as the case of the CFA is one of the very few examples of fixed pegs where the currency decision can be assumed to be exogenous. We claim that the study by Frankel (2008) does not control for multilateral resistance and perhaps for this reason finds large and positive trade 
effects. This emphasizes that the potential bias present in studies investigating trade effects from exchange rate policies using traditional specifications of the gravity model of trade could be large.

It can also be seen as an indicator that unobserved factors, such as other trade-facilitating attempts beside RTAs, well established business links and trade networks, play a much more important role in this particular case of trade between Europe and Sub-Saharan Africa than exchange rate risks. France may serve here as middleman that processes trade from other European countries through its trade network in order to overcome some of these unobserved factors. This has been facilitated by the introduction of the Euro as it has eliminated costs related to currency handling between other EZ members and France, and has possible driven the trade effects found in this paper. Investigating the role of France as a trade hub for Sub-Saharan Africa goes beyond the scope of this paper but provides interesting research opportunities for future studies. 


\section{References}

Aizenman, J. 2018. Optimal Currency Area: A twentieth Century Idea for the twenty-first Century? Open Economies Review 29, 373-382.

Anderson, J.E. \& van Wincoop, E., 2003. Gravity with Gravitas: A Solution to the Border Puzzle. American Economic Review, 93(1), pp.170 - 192.

Auboin, M. \& Ruta, M., 2011. The Relationship Between Exchange Rates and International Trade: A Review of Economic Literature. WTO Working Paper, 17(October).

Bahmani-Oskooee, M. \& Hegerty, S.W., 2007. Exchange rate volatility and trade flows: a review article. Journal of Economic Studies, 34(3), pp.211 - 255.Baldwin, R., Skudelny, F. and Taglioni, D. 2005. Trade Effects of the Euro: Evidence From Sectoral Data. ECB Working Papers, No. 446.

Baldwin, R., 2006. The Euro's Trade Effect. ECB Working Paper Series, 594.

Baldwin, R., Di Nino, V., Fontagné, L., De Santis, R. A. and Taglioni, D., 2008. Study On the Impact of the Euro On Trade and Foreign Direct Investment. European Economy - Economic Papers, No. 321.

Baltagi, B., P. Egger and M. Pfaffermayr (2014), "Panel data gravity models of international trade," CESifo Working Paper No. 4616.

Baranga, T., 2014. Estimating the Effects of Fixed Exchange Rate Regimes on Trade: Evidence from the Formation of the Euro. Department of Economics, UC San Diego. https://gps.ucsd.edu/_files/faculty/baranga/baranga_publications_estimating_effects.pdf.

Carrere, C. 2004. African Regional Agreements: Impact on Trade with or without Currency Unions," Journal of African Economies, Centre for the Study of African Economies (CSAE), vol. 13(2), pp. 199-239.

De Sousa, J., 2012. The currency union effect on trade is decreasing over time. Economics Letters, 117(3), pp. 917-920.

De Sousa, J. \& Lochard, J., 2005. Do Currency Barriers Solve the Border Effect Puzzle? Evidence from the CFA Franc Zone. Review of World Economics, 141(3), pp.422 - 441.

Diallo, O. and Tapsoba, S. J.-A., 2016. Rising BRIC and Changes in Sub-Saharan Africa's Business Cycle Patterns. World Economy 39: 260-284.

Fally, T. 2015. Structural gravity and fixed effects. Journal of International Economics, 97(1), 76-85.

Fielding, D. \& Shields, K., 2005. The Impact of Monetary Union on Macroeconomic Integration: Evidence from West Africa. Economica, 72(288), pp.683 - 704.

Flam, H. and Nordström, H. (2003) 'Trade Volume Effects of the Euro: Aggregate and Sector Estimates'. IIES Seminar Papers, No. 746.

Frankel, J., 2010. The Estimated Trade Effects of the Euro: Why Are They Below Those from Historical Monetary Unions among Smaller Countries?, in Alesina, A and F Giavazzi (eds.), Europe and the Euro, Chicago: University of Chicago Press.

Frankel, J., 2008. The Estimated Effects of the Euro on Trade: Why Are They Below Historical Effects of Monetary Unions Among Smaller Countries? NBER Working Papers, 14542.

Girardini, E. and Sall, C.A.T. 2018. Inflation Dynamics of Franc-Zone Countries Determinants, Comovements and Spatial Interactions. Open Economies Review 29 (2), 295-320.

Glick, R. and Rose, A. 2002. Does a Currency Union Affect Trade? The Time-Series Evidence. European Economic Review, Vol. 46, No. 5, pp. 1125-1151.

Glick, R. and Rose, A. 2016. Currency Unions and Trade: A Post-EMU Reassessment. European Economic Review Vol. 87, pp. 78-91.

Hallet, M., 2008. The role of the Euro in Sub-Saharan Africa and in the CFA franc zone. European Economy Economic Papers, 347.

Head, K., \& Mayer, T. (2014). Gravity Equations: Workhorse, Toolkit, Cookbook. In: Gopinath, G., Helpman, E. \& K. Rogoff (eds.), Handbook of International Economics, Vol. 4. North Holland.

Kelejian, H. G. S. Tavlas P. Petroulas (2012) In the neighborhood: The trade effects of the Euro in a spatial framework, Regional Science and Urban Economics 42 (1-2), 314-322.

Larch, M., Wanner, J., Yotov, Y. and Zylkin, T., 2018. Currency Union and Trade. A PPML Re-Assessment with High-Dimensional Fixed Effects. Oxford Bulleting of Economics \& Statistics, forthcoming. 
Masson, P.R., 2008. Currency Unions in Africa: Is the Trade Effect Substantial Enough to Justify their Formation? The World Economy, 31(4), pp.533 - 547.

Mayer, T. \& Zignago, S., 2011. Notes on CEPII's distances measures: The GeoDist database.

McKenzie, M.D., 1999. The Impact of Exchange Rate Volatility on International Trade Flows. Journal of Economic Surveys, 13(1), pp.71 - 106.Micco, A., Stein, E. and Ordoñez, G. 2003. The Currency Union Effect On Trade: Early Evidence From EMU. Economic Policy, Vol. 18, No. 37, pp. 315-343.

Ozturk, I., 2006. Exchange Rate Volatility and Trade: A Literature Survey. International Journal of Applied Econometrics and Quantitative Studies, 3(1), pp. 85-102.

Rauch, J.E., 1999. Networks versus markets in international trade. Journal of International Economics, 48(1), pp.7-35.

Rose, A.K., 2000. One Money, One Market: Estimating the Effect of Common Currencies on Trade. Economic Policy, 15(30), pp.7-46.

Rose, A.K., 2017. Why do Estimates of the EMU Effect on Trade Vary so Much? Open Economies Review 28 (1), 1-18.

Santos Silva, J. M. C. \& Tenreyro, S., 2006. The Log of Gravity. The Review of Economics and Statistics 88, (4), pp. 641-658.

Tapsoba, S. J.-A., 2009. Trade Intensity and Business Cycle Synchronicity in S. Jules-Armand Africa. Journal of African Economies, Centre for the Study of African Economies (CSAE), 18(2), pp. 287-318.

The Economist, 2018. Francophone Africa's CFA frank is under Fire. Print Edition. Middle East Africa Section. Jan $27^{\text {th }} 2108$.

Tsangarides, C.G., Ewenczyk, P. \& Hulej, M., 2006. Stylized Facts on Bilateral Trade and Currency Unions : Implications for Africa. IMF Working Paper, (WP/06/31).

Zylkin, T., 2017. PPML_PANEL_SG: Stata Module to Estimate "Structural Gravity" Models via Poisson PML. https://ideas.repec.org/c/boc/bcode/s458249.html. 


\section{Appendix}

Table A.1 List of Countries

\begin{tabular}{|c|c|c|c|}
\hline Afghanistan & Côte d'Ivoire & Kuwait & Rwanda \\
\hline Albania & $\begin{array}{l}\text { Dem. Rep. of } \\
\text { Korea }\end{array}$ & Kyrgyzstan & Samoa \\
\hline Algeria & Denmark & $\begin{array}{l}\text { Lao People's Dem. } \\
\text { Rep. }\end{array}$ & Sao Tome and Principe \\
\hline Angola & Djibouti & Latvia & Saudi Arabia \\
\hline Antigua and Barbuda & Dominica & Lebanon & Senegal \\
\hline Argentina & Dominican Rep. & Lesotho & Seychelles \\
\hline Armenia & Ecuador & Liberia & Sierra Leone \\
\hline Australia & Egypt & Libya & Singapore \\
\hline Austria & El Salvador & Lithuania & Slovakia \\
\hline Azerbaijan & Equatorial Guinea & Macao & Slovenia \\
\hline Bahamas & Eritrea & Macedonia & Solomon Isds \\
\hline Bahrain & Estonia & Madagascar & Somalia \\
\hline Bangladesh & Ethiopia & Malawi & South Africa \\
\hline Barbados & Fiji & Malaysia & Spain \\
\hline Belarus & Finland & $\underline{\text { Mali }}$ & Sri Lanka \\
\hline Belgium & France & Malta & Sudan \\
\hline Belize & Gabon & Mauritania & Suriname \\
\hline Benin & Gambia & Mauritius & Swaziland \\
\hline Bermuda & Georgia & Mexico & Sweden \\
\hline Bhutan & Germany & Mongolia & Switzerland \\
\hline Bolivia & Ghana & Morocco & Syria \\
\hline Bosnia Herzegovina & Greece & Mozambique & TFYR of Macedonia \\
\hline Botswana & Guatemala & Namibia & Tajikistan \\
\hline Brazil & Guinea & Nepal & Thailand \\
\hline Brunei Darussalam & Guinea-Bissau & Netherlands & $\underline{\text { Togo }}$ \\
\hline Bulgaria & Guyana & New Zealand & Tonga \\
\hline Burkina Faso & Haiti & Nicaragua & Trinidad and Tobago \\
\hline Burundi & Honduras & $\underline{\text { Niger }}$ & Tunisia \\
\hline Cambodia & Hong Kong & Nigeria & Turkey \\
\hline Cameroon & Hungary & Norway & Turkmenistan \\
\hline Canada & Iceland & Oman & USA \\
\hline Cape Verde & India & Pakistan & Uganda \\
\hline Central African Rep. & Indonesia & Palau & Ukraine \\
\hline Chad & Iran & Panama & United Arab Emirates \\
\hline Chile & Iraq & Papua New Guinea & United Kingdom \\
\hline China & Ireland & Paraguay & United Rep. of Tanzania \\
\hline Colombia & Israel & Peru & Uruguay \\
\hline Comoros & Italy & Philippines & Vanuatu \\
\hline Congo & Jamaica & Poland & Venezuela \\
\hline Costa Rica & Japan & Portugal & Viet Nam \\
\hline Croatia & Jordan & Qatar & Yemen \\
\hline Cuba & Kazakhstan & Rep. of Korea & Zambia \\
\hline Cyprus & Kenya & Rep. of Moldova & Zimbabwe \\
\hline Czech Rep. & Kiribati & Russian Federation & \\
\hline
\end{tabular}

Notes: Bold+ltalic indicates Eurozone membership and bold+underlined indicates CFA membership. 
Table A.2. List of Sectors and Codes

\begin{tabular}{|c|c|c|c|c|c|}
\hline Code & Category & Description & Code & Category & Description \\
\hline 0 & 1 & Live animals chiefly for food & 58 & 3 & $\begin{array}{l}\text { Artificial resins and plastic materials, and cellulose } \\
\text { esters etc }\end{array}$ \\
\hline 1 & 1 & Meat and preparations & 59 & 4 & Chemical materials and products, nes \\
\hline 2 & 1 & Dairy products and birds' eggs & 61 & 4 & $\begin{array}{l}\text { Leather, leather manufactures, nes, and dressed } \\
\text { furskins }\end{array}$ \\
\hline 3 & 1 & $\begin{array}{l}\text { Fish, crustacean and molluscs, and } \\
\text { preparations thereof }\end{array}$ & 62 & 4 & Rubber manufactures, nes \\
\hline 4 & 1 & Cereals and cereal preparations & 63 & 4 & Cork and wood, cork manufactures \\
\hline 5 & 1 & Vegetables and fruit & 64 & 3 & $\begin{array}{l}\text { Paper, paperboard, and articles of pulp, of paper or of } \\
\text { paperboard }\end{array}$ \\
\hline 6 & 1 & Sugar, sugar preparations and honey & 65 & 4 & $\begin{array}{l}\text { Textile yarn, fabrics, made-up articles, nes, and related } \\
\text { products }\end{array}$ \\
\hline 7 & 1 & $\begin{array}{l}\text { Coffee, tea, cocoa, spices, and manufactures } \\
\text { thereof }\end{array}$ & 66 & 4 & Non-metallic mineral manufactures, nes \\
\hline 8 & 1 & $\begin{array}{l}\text { Feeding stuff for animals (not including } \\
\text { unmilled cereals) }\end{array}$ & 67 & 3 & Iron and steel \\
\hline 9 & 1 & $\begin{array}{l}\text { Miscellaneous edible products and } \\
\text { preparations }\end{array}$ & 68 & 3 & Non-ferrous metals \\
\hline 11 & 1 & Beverages & 69 & 4 & Manufactures of metals, nes \\
\hline 12 & 1 & Tobacco and tobacco manufactures & 71 & 4 & Power generating machinery and equipment \\
\hline 21 & 1 & Hides, skins and furskins, raw & 72 & 4 & Machinery specialized for particular industries \\
\hline 22 & 1 & Oil seeds and oleaginous fruit & 73 & 4 & Metalworking machinery \\
\hline 23 & 1 & $\begin{array}{l}\text { Crude rubber (including synthetic and } \\
\text { reclaimed) }\end{array}$ & 74 & 4 & $\begin{array}{l}\text { General industrial machinery and equipment, nes, and } \\
\text { parts of, nes }\end{array}$ \\
\hline 24 & 1 & Cork and wood & 75 & 4 & $\begin{array}{l}\text { Office machines and automatic data processing } \\
\text { equipment }\end{array}$ \\
\hline 25 & 1 & Pulp and waste paper & 76 & 4 & $\begin{array}{l}\text { Telecommunications, sound recording and reproducing } \\
\text { equipment }\end{array}$ \\
\hline 26 & 1 & $\begin{array}{l}\text { Textile fibres (not wool tops) and their } \\
\text { wastes (not in yarn) }\end{array}$ & 77 & 4 & $\begin{array}{l}\text { Electric machinery, apparatus and appliances, nes, and } \\
\text { parts, nes }\end{array}$ \\
\hline 27 & 2 & Crude fertilizer and crude minerals & 78 & 4 & Road vehicles \\
\hline 28 & 2 & Metalliferous ores and metal scrap & 79 & 4 & Other transport equipment \\
\hline 29 & 1 & Crude animal and vegetable materials, nes & 81 & 4 & $\begin{array}{l}\text { Sanitary, plumbing, heating, lighting fixtures and } \\
\text { fittings, nes }\end{array}$ \\
\hline 32 & 2 & Coal, coke and briquettes & 82 & 4 & Furniture and parts thereof \\
\hline 33 & 2 & $\begin{array}{l}\text { Petroleum, petroleum products and related } \\
\text { materials }\end{array}$ & 83 & 4 & Travel goods, handbags and similar containers \\
\hline 34 & 2 & Gas, natural and manufactured & 84 & 4 & Articles of apparel and clothing accessories \\
\hline 35 & 2 & Electric current & 85 & 4 & Footwear \\
\hline 41 & 1 & Animal oils and fats & 87 & 4 & $\begin{array}{l}\text { Professional, scientific, controlling instruments, } \\
\text { apparatus, nes }\end{array}$ \\
\hline 42 & 1 & Fixed vegetable oils and fats & 88 & 4 & $\begin{array}{l}\text { Photographic equipment and supplies, optical goods; } \\
\text { watches, etc }\end{array}$ \\
\hline 43 & 1 & $\begin{array}{l}\text { Animal and vegetable oils and fats, } \\
\text { processed, and waxes }\end{array}$ & 89 & 4 & Miscellaneous manufactured articles, nes \\
\hline 51 & 3 & Organic chemicals & 91 & 4 & Postal packages not classified according to kind \\
\hline 52 & 2 & Inorganic chemicals & 94 & 1 & $\begin{array}{l}\text { Animals, live, nes, (including zoo animals, pets, insects, } \\
\text { etc) }\end{array}$ \\
\hline 53 & 3 & Dyeing, tanning and colouring materials & 95 & 4 & $\begin{array}{l}\text { Armoured fighting vehicles, war firearms, ammunition, } \\
\text { parts, nes }\end{array}$ \\
\hline 54 & 3 & Medicinal and pharmaceutical products & 96 & 3 & Coin (other than gold coin), not being legal tender \\
\hline 55 & 4 & $\begin{array}{l}\text { Oils and perfume materials; toilet and } \\
\text { cleansing preparations }\end{array}$ & 97 & 2 & $\begin{array}{l}\text { Gold, non-monetary (excluding gold ores and } \\
\text { concentrates) }\end{array}$ \\
\hline 56 & 3 & Fertilizers, manufactured & & & \\
\hline 57 & 3 & Explosives and pyrotechnic products & & & \\
\hline
\end{tabular}

Note: Categories 1, 2, 3 and 4 denote respectively agricultural products, minerals, homogenous and referenced priced manufactured products and differentiated manufactured products. Rauch (1999) classification. 
Table A.3 Variable, description and sources

\begin{tabular}{|c|c|c|}
\hline Variable & Description & Source \\
\hline $\begin{array}{l}\text { In } \\
\text { Exports }_{\mathrm{ijkt}}\end{array}$ & $\begin{array}{l}\text { Log of average yearly nominal exports of good } k \text { from country } i \text { to } j \text { at time } t \text { in } \\
\text { current US\$ }\end{array}$ & $\begin{array}{l}\text { UN Comtrade 2-digit SITC Rev. } \\
2\end{array}$ \\
\hline In GDP ${ }_{\text {it }}$ & Log of the nominal GDP of country $i$ at time $t$ in current US\$ & World Development Indicators \\
\hline $\operatorname{Ln}_{\mathrm{GDP}} \mathrm{jt}$ & Log of the nominal GDP of country $j$ at time $t$ in current US\$ & World Development Indicators \\
\hline In Distance ${ }_{i j}$ & Log of distance between capitals of country $\mathrm{i}$ and $\mathrm{j}$ in $\mathrm{km}$ & CEPII \\
\hline CFAEZ $_{\mathrm{ijt}}$ & $\begin{array}{l}\text { Dummy that takes the value of } 1 \text { if } i \text { is a CFA member and } j \text { is a Eurozone } \\
\text { member at time } t, 0 \text { otherwise }\end{array}$ & BCEAO / BEAC / Eurostat \\
\hline EZCFA $_{\text {ijt }}$ & $\begin{array}{l}\text { Dummy that takes the value of } 1 \text { if } \mathrm{i} \text { is a Eurozone member and } \mathrm{j} \text { is a CFA } \\
\text { member at time } t, 0 \text { otherwise }\end{array}$ & BCEAO / BEAC / Eurostat \\
\hline IntraCFA $A_{i j t}$ & $\begin{array}{l}\text { Dummy that takes the value of } 1 \text { after } 1999 \text { if } \mathrm{i} \text { and } \mathrm{j} \text { are both CFA members, } 0 \\
\text { otherwise }\end{array}$ & BCEAO / BEAC / Eurostat \\
\hline CFAFrance $_{\mathrm{ijt}}$ & $\begin{array}{l}\text { Dummy that takes the value of } 1 \text { after } 1999 \text { if } i \text { is a CFA member and } j \text { is France, } \\
\text { zero otherwise }\end{array}$ & BCEAO / BEAC / Eurostat \\
\hline FranceCFA $\mathrm{ijt}_{\mathrm{i}}$ & $\begin{array}{l}\text { Dummy that takes the value of } 1 \text { after } 1999 \text { if } i \text { is France and importer } j \text { is a CFA } \\
\text { member, } 0 \text { otherwise }\end{array}$ & BCEAO / BEAC / Eurostat \\
\hline Border $_{\mathrm{ij}}$ & $\begin{array}{l}\text { Dummy that takes the value of } 1 \text { if } \mathrm{i} \text { and } \mathrm{j} \text { share a common border, zero } \\
\text { otherwise }\end{array}$ & CEPII \\
\hline Language $_{i j}$ & $\begin{array}{l}\text { Dummy that takes the value of } 1 \text { if the same language is spoken by at least } 9 \% \\
\text { of the population in } \mathrm{i} \text { and } \mathrm{j}\end{array}$ & CEPII \\
\hline Colony $_{\mathrm{ij}}$ & Dummy that takes the value of 1 if $\mathrm{i}$ is and $\mathrm{j}$ ever had a colonial link, 0 otherwise & CEPII \\
\hline RTA $_{\mathrm{ijt}}$ & Dummy that takes the value of 1 if $i$ and $j$ have signed a RTA, 0 otherwise & De Sousa (2012) \\
\hline $\mathrm{CU}_{\mathrm{ijt}}$ & Dummy that takes the value of 1 if $i$ and $j$ have the same currency, 0 otherwise & De Sousa (2012) \\
\hline
\end{tabular}


Table A.4. Replication of Table 7A in Frankel (2008) with sectoral data

\begin{tabular}{|c|c|c|c|c|}
\hline & OLS & BIL_FE & BSFE-MRT & OLS, Frankel (2008) \\
\hline & (1) & $(2)$ & (3) & $(4)$ \\
\hline Dep. Variable: & Exports & Exports & Exports & X_Aggregated \\
\hline \multicolumn{5}{|l|}{ Expl. Variables: } \\
\hline \multirow[t]{2}{*}{ RTA } & $1.210 * * *$ & $0.201 * * *$ & $0.162 * * *$ & $1.940 * * *$ \\
\hline & [0.0589] & {$[0.0197]$} & {$[0.0191]$} & {$[0.182]$} \\
\hline \multirow[t]{2}{*}{ COMCUR } & 0.243 & $0.273 * * *$ & $0.156^{* *}$ & $1.710 * * *$ \\
\hline & {$[0.257]$} & {$[0.0810]$} & {$[0.0647]$} & {$[0.389]$} \\
\hline \multirow[t]{2}{*}{ EURO } & $1.063 * * *$ & $0.132 *$ & $0.163 * *$ & $0.229 *$ \\
\hline & {$[0.237]$} & {$[0.0783]$} & {$[0.0711]$} & {$[0.138]$} \\
\hline \multirow[t]{2}{*}{ CFA } & -0.152 & 0.0647 & 0.179 & $-0.726^{*}$ \\
\hline & {$[0.211]$} & {$[0.107]$} & {$[0.218]$} & {$[0.439]$} \\
\hline \multirow[t]{2}{*}{ CFAEZ_95 } & $-0.498 * * *$ & $-0.268 * * *$ & -0.241 & 0.237 \\
\hline & {$[0.0674]$} & {$[0.0464]$} & {$[0.188]$} & {$[0.166]$} \\
\hline \multirow[t]{2}{*}{ CFAEZ_96 } & $-0.550 * * *$ & $-0.193 * * *$ & -0.164 & 0.079 \\
\hline & {$[0.0650]$} & {$[0.0460]$} & [0.187] & {$[0.158]$} \\
\hline \multirow[t]{2}{*}{ CFAEZ_97 } & $-0.582 * * *$ & $-0.225 * * *$ & -0.202 & $0.640 * * *$ \\
\hline & {$[0.0626]$} & {$[0.0429]$} & {$[0.185]$} & {$[0.226]$} \\
\hline \multirow[t]{2}{*}{ CFAEZ_98 } & $-0.496 * * *$ & $-0.105 * *$ & -0.0611 & $0.549 * *$ \\
\hline & [0.0646] & [0.0411] & {$[0.185]$} & {$[0.222]$} \\
\hline \multirow[t]{2}{*}{ CFAEZ_99 } & $0.145 * * *$ & $-0.202 * * *$ & $0.0982 * *$ & $0.508 * *$ \\
\hline & {$[0.0455]$} & [0.0198] & [0.0422] & {$[0.222]$} \\
\hline \multirow[t]{2}{*}{ CFAEZ_00 } & $0.280 * * *$ & $-0.150 * * *$ & $0.148 * * *$ & $0.450 * *$ \\
\hline & {$[0.0465]$} & [0.0206] & [0.0422] & {$[0.223]$} \\
\hline \multirow[t]{2}{*}{ CFAEZ_01 } & $0.225 * * *$ & $-0.133 * * *$ & $0.142 * * *$ & $0.546 * *$ \\
\hline & {$[0.0451]$} & [0.0207] & [0.0412] & {$[0.223]$} \\
\hline \multirow[t]{2}{*}{ CFAEZ_02 } & $0.237 * * *$ & $-0.164 * * *$ & $-0.213 * * *$ & $0.519 * *$ \\
\hline & {$[0.0457]$} & [0.0214] & [0.0480] & {$[0.226]$} \\
\hline \multirow[t]{2}{*}{ CFAEZ_03 } & $0.314 * * *$ & $-0.119 * * *$ & $-0.172 * * *$ & $0.428 *$ \\
\hline & {$[0.0457]$} & {$[0.0222]$} & [0.0480] & [0.233] \\
\hline \multirow[t]{2}{*}{ CFAEZ_04 } & $0.331 * * *$ & $-0.0791 * * *$ & $-0.137 * * *$ & $0.437 *$ \\
\hline & {$[0.0465]$} & [0.0229] & [0.0479] & {$[0.235]$} \\
\hline \multirow[t]{2}{*}{ CFAEZ_05 } & $0.310 * * *$ & $-0.103 * * *$ & $-0.168 * * *$ & 0.22 \\
\hline & {$[0.0488]$} & {$[0.0241]$} & [0.0482] & {$[0.238]$} \\
\hline \multirow[t]{2}{*}{ CFAEZ_06 } & $0.470 * * *$ & -0.0168 & $-0.145^{* * *}$ & 0.178 \\
\hline & {$[0.0481]$} & [0.0239] & [0.0399] & {$[0.246]$} \\
\hline \multirow[t]{2}{*}{ CFAEZ_07 } & $0.338 * * *$ & -0.0318 & $-0.151 * * *$ & \\
\hline & {$[0.0470]$} & [0.0239] & [0.0396] & \\
\hline \multirow[t]{2}{*}{ CFAEZ_08 } & $0.114 * *$ & $-0.0462 *$ & $-0.171 * * *$ & \\
\hline & {$[0.0477]$} & [0.0246] & [0.0392] & \\
\hline CFAEZ_09 & $0.0989 * *$ & $-0.0506 * *$ & $-0.175 * * *$ & \\
\hline & {$[0.0476]$} & [0.0253] & [0.0399] & \\
\hline Ln GDP & $0.607 * * *$ & $0.811 * * *$ & $0.603 * * *$ & $0.813 * * *$ \\
\hline & [0.0116] & {$[0.0238]$} & [0.0307] & {$[0.016]$} \\
\hline Ln distance & $-0.434 * * *$ & & & - \\
\hline & [0.0254] & & & - \\
\hline Landlocked & $-0.986 * * *$ & & & $-0.267 * * *$ \\
\hline & [0.0334] & & & [0.049] \\
\hline Colony & $1.973 * * *$ & & & $1.004 * * *$ \\
\hline & {$[0.120]$} & & & [0.149] \\
\hline Com. language & $0.119 * *$ & & & $0.358 * * *$ \\
\hline & {$[0.0565]$} & & & {$[0.073]$} \\
\hline Contiguity & $2.387 * * *$ & & & $2.515 * * *$ \\
\hline & {$[0.110]$} & & & {$[0.134]$} \\
\hline Observations & 617,629 & 617,629 & 617,629 & 169,561 \\
\hline R-squared & 0.251 & 0.086 & 0.118 & 0.40 \\
\hline
\end{tabular}


Note: Robust standard errors clustered at the bilateral level are in brackets. ${ }^{* * *} \mathrm{p}<0.01,{ }^{* *} \mathrm{p}<0.05, * \mathrm{p}<0.1$. BSFE denotes bilateral-sectoral fixed effects. MRT denotes multilateral resistance terms specified as exporter-time and importer-time dummy variables for 4 year periods. Estimations based on yearly data. CFAEZ is a dummy variable that takes the value of 1 if $i$ is a CFA member and $\mathrm{j}$ is a Eurozone member -excluding France- at time $\mathrm{t}, 0$ otherwise and also when $\mathrm{i}$ is a Eurozone member excluding France- and $j$ is a CFA member at time $t, 0$ otherwise. The rest of variables are defined in Table A.3. id denotes the cross-section identifier, which is origin-destination-sector. 
Table A.5 Estimation results for the extended period with PPML

\begin{tabular}{|c|c|c|c|c|c|c|}
\hline Dep. & (1) & $(2)$ & (3) & (4) & (5) & $(6)$ \\
\hline Variable: & Xtot & Xnoen & Xfood & Xrawm & Xmatchtr & Xotherm \\
\hline \multicolumn{7}{|c|}{ Expl. Variables: } \\
\hline \multirow[t]{2}{*}{ COMCUR } & -0.0237 & 0.0291 & $-0.199 * *$ & -0.0540 & 0.133 & -0.0159 \\
\hline & [0.0826] & [0.0676] & [0.0857] & [0.133] & [0.0965] & [0.0717] \\
\hline \multirow[t]{2}{*}{ RTA } & $0.119 * * *$ & $0.120 * * *$ & $0.172 * *$ & -0.0359 & $0.0918 * * *$ & $0.182 * * *$ \\
\hline & [0.0396] & [0.0374] & [0.0735] & [0.0602] & [0.0349] & [0.0311] \\
\hline \multirow[t]{2}{*}{ EURO } & -0.0215 & -0.0778 & $0.260 * * *$ & $0.214^{*}$ & $-0.193 * *$ & 0.0243 \\
\hline & {$[0.0741]$} & {$[0.0674]$} & [0.0898] & [0.115] & [0.0841] & [0.0624] \\
\hline \multirow[t]{2}{*}{ CFA } & 0.754 & 0.722 & $1.242 * * *$ & -1.387 & $0.670 * *$ & $0.983 * * *$ \\
\hline & [0.483] & [0.502] & [0.355] & [1.188] & [0.306] & [0.266] \\
\hline \multirow[t]{2}{*}{ EZCFA } & -0.232 & -0.234 & -0.269 & $-0.844 *$ & 0.111 & -0.196 \\
\hline & [0.203] & [0.193] & [0.174] & [0.444] & [0.114] & [0.131] \\
\hline \multirow[t]{2}{*}{ CFAEZ } & -0.116 & -0.150 & $0.614^{* * *}$ & 0.0564 & $0.594 * *$ & $0.531^{*}$ \\
\hline & [0.287] & [0.243] & [0.198] & [0.214] & [0.281] & [0.301] \\
\hline BFE & Yes & Yes & Yes & Yes & Yes & Yes \\
\hline Observations & 717,405 & 714,817 & 327,586 & 279,709 & 309,175 & 356,350 \\
\hline R-squared & 0.994 & 0.995 & 0.987 & 0.988 & 0.986 & 0.976 \\
\hline
\end{tabular}

Note: Robust standard errors in brackets. ${ }^{* *} p<0.01,{ }^{* *} p<0.05,{ }^{*} p<0.1$. BFE denotes bilateral fixed effects. MRT denotes multilateral resistance terms specified as exporter-year and importer-year dummy variables. Xtot denotes total exports, Xnoen excludes energy exports, Xfood denotes exports in agricultural products, Xrawmat exports in raw materials, Xmachtr in machinery and transport equipment and Xotherm in other manufacturing industries. CFAEZ is a dummy variable that takes the value of 1 if $i$ is a CFA member and $j$ is a Eurozone member -excluding France- at time $t, 0$ otherwise. EZCFA is dummy variable that takes the value of 1 if $i$ is a Eurozone member -excluding France- and $j$ is a CFA member at time $t, 0$ otherwise. The rest of variables are defined in Table A.3. id denotes the cross-section identifier, which is origin-destination. 
Table A.6. Estimation results for extended period including separated effects for WAEMU and CEMAC

\begin{tabular}{|c|c|c|c|c|c|c|}
\hline $\begin{array}{l}\text { Dep. } \\
\text { Variable: }\end{array}$ & $\begin{array}{c}(1) \\
\text { Xtot }\end{array}$ & $\begin{array}{c}(2) \\
\text { Xnoen } \\
\end{array}$ & $\begin{array}{c}(3) \\
\text { Xfood }\end{array}$ & $\begin{array}{c}(4) \\
\text { Xrawm } \\
\end{array}$ & $\begin{array}{c}(5) \\
\text { Xmatchtr } \\
\end{array}$ & $\begin{array}{c}(6) \\
\text { Xotherm }\end{array}$ \\
\hline \multicolumn{7}{|l|}{ Expl. Variables: } \\
\hline WAEMU & $\begin{array}{c}1.030 * * * \\
{[0.307]}\end{array}$ & $\begin{array}{c}0.957^{* * *} \\
{[0.320]}\end{array}$ & $\begin{array}{c}1.511 * * * \\
{[0.387]}\end{array}$ & $\begin{array}{l}-2.148 \\
{[1.406]}\end{array}$ & $\begin{array}{c}0.723^{* *} \\
{[0.334]}\end{array}$ & $\begin{array}{c}0.985^{* * *} \\
{[0.353]}\end{array}$ \\
\hline CEMAC & $\begin{array}{c}0.873 \\
{[0.604]}\end{array}$ & $\begin{array}{c}0.762 \\
{[0.596]}\end{array}$ & $\begin{array}{l}0.825^{*} \\
{[0.476]}\end{array}$ & $\begin{array}{c}0.444 \\
{[0.790]}\end{array}$ & $\begin{array}{c}0.32 \\
{[0.524]}\end{array}$ & $\begin{array}{c}1.225 \\
{[0.765]}\end{array}$ \\
\hline EZWAEMU & $\begin{array}{c}-0.309^{* *} \\
{[0.139]}\end{array}$ & $\begin{array}{c}-0.372^{* * *} \\
{[0.136]}\end{array}$ & $\begin{array}{c}-0.246 \\
{[0.203]}\end{array}$ & $\begin{array}{c}-0.984^{* * *} \\
{[0.358]}\end{array}$ & $\begin{array}{l}-0.211 \\
{[0.157]}\end{array}$ & $\begin{array}{c}-0.339^{* *} \\
{[0.139]}\end{array}$ \\
\hline EZCEMAC & $\begin{array}{l}-0.113 \\
{[0.160]}\end{array}$ & $\begin{array}{l}-0.0490 \\
{[0.158]}\end{array}$ & $\begin{array}{c}-0.357^{* *} \\
{[0.175]}\end{array}$ & $\begin{array}{l}-0.304 \\
{[0.334]}\end{array}$ & $\begin{array}{l}-0.414^{*} \\
{[0.228]}\end{array}$ & $\begin{array}{l}-0.0951 \\
{[0.182]}\end{array}$ \\
\hline WAEMUEZ & $\begin{array}{c}0.124 \\
{[0.160]}\end{array}$ & $\begin{array}{l}0.0490 \\
{[0.158]}\end{array}$ & $\begin{array}{l}0.702^{*} \\
{[0.406]}\end{array}$ & $\begin{array}{c}-0.102 \\
{[0.237]}\end{array}$ & $\begin{array}{c}0.494^{* *} \\
{[0.254]}\end{array}$ & $\begin{array}{l}0.541^{*} \\
{[0.261]}\end{array}$ \\
\hline CEMACEZ & $\begin{array}{l}-0.113 \\
{[0.130]}\end{array}$ & $\begin{array}{l}-0.0490 \\
{[0.258]}\end{array}$ & $\begin{array}{c}0.532^{* *} \\
{[0.219]}\end{array}$ & $\begin{array}{l}0.411^{*} \\
{[0.236]}\end{array}$ & $\begin{array}{c}0.285 \\
{[0.254]}\end{array}$ & $\begin{array}{l}-2.400 \\
{[1.736]}\end{array}$ \\
\hline BFE & Yes & Yes & Yes & Yes & Yes & Yes \\
\hline Observations & 717,405 & 714,817 & 327,586 & 279,709 & 309,175 & 356,350 \\
\hline R-squared & 0.998 & 0.989 & 0.989 & 0.991 & 0.961 & 0.967 \\
\hline
\end{tabular}

Note: Robust standard errors cluster by pair are in brackets, ${ }^{* * *} p<0.01,{ }^{* *} p<0.05,{ }^{*} p<0.1$. BFE denotes bilateral fixed effects. MRT denotes multilateral resistance terms specified as exporter-year and importer-year dummy variables. Xtot denotes total exports, Xnoen excludes energy exports, Xfood denotes exports in agricultural products, Xrawmat exports in raw materials, Xmachtr in machinery and transport equipment and Xotherm in other manufacturing industries. WAEMU (CEMAC) are dummy variables that take the value of 1 if country $i$ and $j$ are WAEMU (CEMAC) members after 1999, 0 otherwise. WAEMUEZ is a dummy variable that takes the value of 1 if $i$ is a WAEMU member and $j$ is a Eurozone member -excluding France- at time $t$, and EZWAEMU when $i$ is a Eurozone member excluding France- and $\mathrm{j}$ is a WAEMU member at time $t, 0$ otherwise. EZCEMAC is dummy variable that takes the value of 1 if $i$ is a Eurozone member -excluding France- and $j$ is a CEMAC member at time $t$, and CEMACEZ when $i$ is a CEMAC member and $j$ is a Eurozone member -excluding France- at time $t, 0$ otherwise. The coefficients of the rest of variables (COMCUR, RTA and EURO) are not shown to save space. 